\title{
The Role of Human Resource Management in Service Sectors during Covid-19 Pandemic
}

$\begin{array}{lr}\text { Santi } \\ \text { Submitted Date: } & \begin{array}{r}\text { Sekolah Tinggi IImu Ekonomi BISMA LEPISI } \\ \text { santi@lepisi.ac.id }\end{array} \\ \begin{array}{l}\text { Athea Sarastiani } \\ \text { Universitas Trisakti }\end{array} \\ \begin{array}{l}\text { Accepted Date: } \\ 6 \text { Mei 2021 }\end{array} & \begin{array}{r}\text { athea.sarastiani@gmail.com } \\ \text { Lianna Wijaya* }\end{array} \\ & \begin{array}{r}\text { Universitas Bina Nusantara } \\ \text { lianna.wijaya@binus.ac.id }\end{array} \\ \begin{array}{r}\text { Sarfilianty Anggiani } \\ \text { Universitas Trisakti } \\ \text { sarfilianty@trisakti.ac.id }\end{array}\end{array}$

\section{Suggested Citation:}

Koohang, A., Paliszkiewicz, J., \& Goluchowski, J. (2017). The impact of leadership on trust, knowledge management, and organizational performance: A research model. Industrial Management and Data Systems, 117(3), 521-537. https://doi.org/10.1108/IMDS-02-2016-0072

\section{Abstract:}

In today's business world, human resources are considered as an important resource for the organization's success. To make better use of human resources, organizations must empower their employees This study aims to determine the impact of leading organization and leading people on trust and the organizational performance in the service sectors during Covid19 pandemic. The research is quantitative, and the sampling technique is purposive sampling, with 103 respondents. Data collected were analyzed using Partial Least Squares path modeling to test the hypotheses. The study's findings proved positive and significant linear relationship between leading people on trust and organizational performance. Managerial implication that the success leader in service sectors able to elevate trust among people, motivate the employees and to enhance organizational performance. As result, leadership training and elevate the trust amongst employees are the most essential strategies in service sectors during the Covid-19 pandemic.

Keywords: Covid-19, Leading Organization, Leading People, Organizational Performance, Trust

Abstrak:

Dalam dunia bisnis saat ini, sumber daya manusia dianggap sebagai sumber daya penting bagi kesuksesan organisasi. Untuk memanfaatkan sumber daya manusia dengan lebih baik, organisasi harus memberdayakan karyawannya Penelitian ini bertujuan untuk menentukan dampak leading organization dan leading people pada kepercayaan dan kinerja organisasi di sektor layanan selama pandemi Covid-19. Penelitian ini adalah penelitian kuantitatif, dan teknik pengambilan sampel adalah purposive sampling, dengan 103 responden. Data yang dikumpulkan dianalisis menggunakan pemodelan jalur Partial Least Squares untuk menguji hipotesis. Temuan penelitian ini membuktikan hubungan linier yang positif dan signifikan antara leading people kepada kepercayaan dan kinerja organisasi. Implikasi maajerial dimana keberhasilan pemimpin di sektor jasa harus mampu meningkatkan kepercayaan di antara karyawan, memotivasi para karyawan dan meningkatkan kinerja organisasi. Sebagai hasilnya, pelatihan kepemimpinan dan meningkatkan kepercayaan di antara karyawan adalah strategi paling penting di sektor jasa selama pandemi Covid-19

Keywords: Covid-19, Leading Organization, Leading People, Organizational Performance, Trust

\section{JEL Classification: M12}




\section{Introduction}

The pandemic starting from China in the end of 2019, the novel Covid-19 has affected every business area around the globe especially the service industry is far below estimates (Škare, Soriano, and Porada-Rochoń 2021). Research records in middle year of 2020, six months after the pandemic outbreak spread (Collins-Kreiner and Ram 2020), the stakeholders and service sectors entrepreneurs have not been able to predict and create scenarios of the impact of this unprecedented crisis. Due the Covid-19, the service sector is facing extra ordinary impact radical changes.

In this pandemic, the stakeholders and service sectors entrepreneurs are requiring favours from their employees greater than before. They can have the positive teamwork of employees, only when the human resource management involvement managing each of service personnel completely. In service industries, commitment and motivation of employees is 'must', because with the motivation and committed employees will surely provide excellent quality service to the customers (Al-Madi et al., 2017).

The fact is that an organized service sectors provide employment to a large number. Therefore, for the human resource management, managing human resources in organized service sectors is more critical. In addition, with the outbreak of pandemic, handling workforce issues which were already a challenge for human resource management has now turned out to be more challenging.

The rapid growth of service industries in the past two decade and currently have challenge during pandemic Covid-19. Due to the nature of service industry organization will always proceed to economic openness, carry out an information revolution by adapting various methods, concentrate on capital resources through polarization, develop and maintain through intangible matters, make resources have deep-rooted values as capital competition in the service sectors market. The capabilities generated then interacted with human elements, values, beliefs, and skills which will be the most effective, influential, and need to be adapted in the organizational management (Koohang, Paliszkiewicz, and Goluchowski 2017).

The challenges that are present require organizations to survive in various ways including through various processes that the organization needs to do, where to pursue its success, the organization must be able to learn and continue to learn. This learning process begins with a culture in such a way that all activities that reflect business continuity, through this process, can be ensured that the organization will continue to improve and ultimately have an impact on organizational performance. To stimulate and guide employees in the service industry towards the organizational performance of the organization, understand the Human Resource Management (HRM) within this organization.

For almost more than a decade, management researchers have increasingly shifted from being just control-oriented to commitment (Verburg et al. 2018). Leadership is important in all level of organization (Koohang, Paliszkiewicz, and Goluchowski 2017). The leadership skills such as motivating, encouraging, and recognizing people provide positive results (Gill, Flaschner, and Shachar 2006). The effective leadership will affect and influence job satisfaction, trustful environment, knowledge management, positive relationships and improved organizational performance (Avolio et al. 2004; Dasborough 2006; Mastrangelo, Eddy, and Lorenzet 2014; Paliszkiewicz, Gołuchowski, and Koohang 2015).

The previous studies that have researched about the positive impact of leadership on performance, creativity, teamwork and/or trust (Anggiani, 2020; Lee et al., 2011; Schaubroeck et al., 2011; Wang et al., 2014). This study explores the relationship between leading organization and leading people on trust and organizational performance, where it is argued that an effective leadership organization results in an increase to trust which finally leads to the success of organizational performance.

The purpose of the study is to prove that effective in leading organization and leading people will build trust and finally to develop the organizational performance in service sectors during pandemic Covid-19. The result will strengthen the previous research about the importance of the leadership in organization to build trust and to enhance the organizational performance. Completely the research, the researcher will furnish the results, the discussion of findings, and implications for future research complete the paper.

\section{Research Method}

The type of research used is quantitative data focusing on numerical data or scoring qualitative data. This analysis is used to analyse the impact of leading organization (LO) and leading people (LP) on trust (TR) and organizational performance (OP) as variables in this study. The data obtained in the form of respondents' responses to these variables are expressed in numbers. The model in this study is presented in the image below. 
Figure 1. Research Model

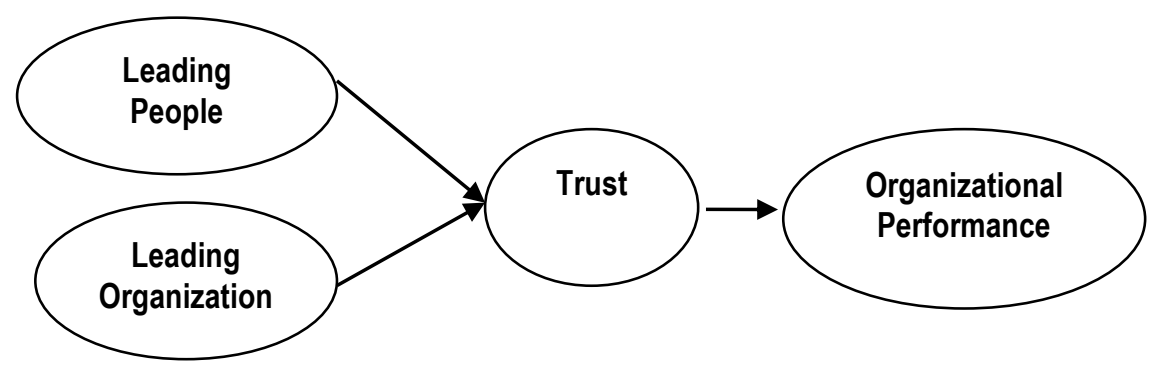

Source: Secondary data (2021)

The model of framework research builds four constructs or latent variables (LVs). Each Latent Variable contains several related characteristics or indicators with their operational definitions. These Latent Variables are Leading Organization (LO), Leading People (LP), Trust (TR), and Organizational Performance (OP). Subsequently, we occur the study's hypotheses based on the research model. The methodology goes along with the study's hypotheses and includes an explanation of the model, the population sample, study procedure and data analysis techniques used to test the hypotheses.

Our aim is to prove that effective leadership in leading organization and leading people are the justification to raise the trust and to enhance the organizational performance. We submitted that effective leadership in leading organization and leading people can positively influence the elevated trust among employees within the organizations and develop the following three hypotheses:

H1. The effective leadership in leading organization positively and significantly contributes to the elevated trust.

H2. The effective leadership in leading people positively and significantly effect to raise the trust.

H3. The elevated trust effect to the organizational performance.

The online questionnaire was used in this research as it was easy to distribute, and the data collection was fast. The questionnaires were distributed directly by using online (Google Forms) to the respondents. The study using five-point Likert scale (i.e., $1=$ strongly disagree to $5=$ strongly agree) as measurement tool to answer the statement of each agreement. This study used the partial least squares structural equation modelling (PLS-SEM) approach to test the hypotheses. The researcher implements purposive sampling to take samples with specific considerations and objectives, to meet the sample eligibility standards. The population is determined in the DKI Jakarta region, samples are 103 respondents who are working in service sectors such as travel agents, hotels, university, hospitals, and transportations operator. The respondents are the employees in the relevant service sectors.

\section{Results}

According to the data respondents based on gender, the percentage of female respondents was $52.43 \%$, the male was $47.57 \%$. Based on the respondents' gender characteristics female respondents were more numerous than male. Thus, there are many female employees in service sectors. The second segmentation is based on age. Most respondents or $33.01 \%$ were at $21-30$ years old, the second was at $31-40$ years old or by $30.10 \%$, the third was at $41-50$ years old or $19.42 \%$, the respondents at $51-60$ years old was $14.56 \%$ and the smallest was above 61 years at $2.91 \%$. The next is based on occupation, First, $56.31 \%$ as travel consultant, the second was at $20.39 \%$ as hoteliers, the third was at $18.45 \%$ as airlines crew and $4.84 \%$ as other occupations in service sectors such as lecturers, doctors, and government public service staffs.

The questionnaire consists of 20 questions: Leading Organization (LO), Leading People (LP), Trust (TR) and Organizational Performance (OP): each consists of four questions, Leading Organization (LO) consists of 4 questions, Leading People (LP) consists of 6 questions, Trust (TR) consist of 6 questions and the Organizational 
Performance (OP) consists of 4 questions. All statement in questionnaire have passed validity test because $R$ value is more than 0,7 for all statement.

Table 1. Validity Test

\begin{tabular}{|c|c|c|}
\hline Items & R Stat & Decision \\
\hline $\begin{array}{l}\text { Leading Organization-LO1 } \\
\text { The ability of leader to influence organization positively }\end{array}$ & 0.893 & Valid \\
\hline $\begin{array}{l}\text { Leading Organization-LO2 } \\
\text { The ability of leader to lead change within the organization }\end{array}$ & 0.905 & Valid \\
\hline $\begin{array}{l}\text { Leading Organization-LO3 } \\
\text { The ability of leader to lead innovation within the organization }\end{array}$ & 0.870 & Valid \\
\hline $\begin{array}{l}\text { Leading Organization-LO4 } \\
\text { The ability of leader to work together to increase } \\
\text { effectiveness within the organizational }\end{array}$ & 0.729 & Valid \\
\hline $\begin{array}{l}\text { Leading People-LP1 } \\
\text { The ability of leader to motivate and emphasize the best } \\
\text { ability in people }\end{array}$ & 0.786 & Valid \\
\hline $\begin{array}{l}\text { Leading People-LP2 } \\
\text { The ability of leader to empower the employees }\end{array}$ & 0.700 & Valid \\
\hline $\begin{array}{l}\text { Leading People-LP3 } \\
\text { The ability of leader to be a good listener and encourage the } \\
\text { employees }\end{array}$ & 0.890 & Valid \\
\hline $\begin{array}{l}\text { Leading People-LP4 } \\
\text { The ability of leader to develop and maintain the relationship } \\
\text { within the employees }\end{array}$ & 0.884 & Valid \\
\hline $\begin{array}{l}\text { Leading People-LP5 } \\
\text { The leader must have good interpersonal communication to } \\
\text { work together and lead effectively }\end{array}$ & 0.832 & Valid \\
\hline $\begin{array}{l}\text { Leading People-LP6 } \\
\text { The ability of leader to handle the conflict within the } \\
\text { organization }\end{array}$ & 0.858 & Valid \\
\hline $\begin{array}{l}\text { Trust-TR1 } \\
\text { The ability of leader to evolved trust among the employees }\end{array}$ & 0.892 & Valid \\
\hline $\begin{array}{l}\text { Trust-TR2 } \\
\text { The ability of leader to lead with sympathy and empathy to } \\
\text { the employees }\end{array}$ & 0.869 & Valid \\
\hline $\begin{array}{l}\text { Trust-TR3 } \\
\text { The leader demonstrate the ability to develop and create the } \\
\text { trust within employees }\end{array}$ & 0.852 & Valid \\
\hline $\begin{array}{l}\text { Trust-TR4 } \\
\text { The leader showing transparency to building trust among the } \\
\text { employees }\end{array}$ & 0.842 & Valid \\
\hline $\begin{array}{l}\text { Trust-TR5 } \\
\text { The leader's honesty and truth in leading contribute to } \\
\text { elevate trust of the employees }\end{array}$ & 0.799 & Valid \\
\hline $\begin{array}{l}\text { Trust-TR6 } \\
\text { The leader's consistency in doing things to evolve the trust } \\
\text { among the employees }\end{array}$ & 0.818 & Valid \\
\hline $\begin{array}{l}\text { Organizational Performance-OP1 The ability to perform the } \\
\text { desired result to showing the effectiveness }\end{array}$ & 0.829 & Valid \\
\hline $\begin{array}{l}\text { Organizational Performance-OP2 } \\
\text { The ability to perform the job tasks with minimum resources } \\
\text { for efficiency }\end{array}$ & 0.858 & Valid \\
\hline $\begin{array}{l}\text { Organizational Performance-OP3 The ability to state of being } \\
\text { productive }\end{array}$ & 0.809 & Valid \\
\hline $\begin{array}{l}\text { Organizational Performance-OP4 } \\
\text { The ability to gain a financial profit and competitive } \\
\text { advantages }\end{array}$ & 0.837 & Valid \\
\hline
\end{tabular}

Source: Secondary data (2021) 
The measurement model results shows in table 2 that convergent validity results show that the value of all items has a loading factor value greater than 0.5 . It can be concluded that all indicators of variable construction: Leading Organization, Leading People, Trust, and Organizational Performance are valid. The AVE value in each latent variable is greater than 0.5 which means each variable can explain $50 \%$ or more to that variable. This means that each variable is also declared valid and meets the convergent validity criteria shown in Table 2.

Table 2. Ave Result

\begin{tabular}{lcc}
\hline Variables & AVE Value & Conclusion \\
\hline Leading Organization & 0.726 & Valid \\
Leading People & 0.685 & Valid \\
Trust & 0.694 & Valid \\
Organizational Performance & 0.716 & Valid \\
\hline
\end{tabular}

Source: Secondary data (2021)

Reliability test in table 3 shows that each item of variable questions, namely leading organization, leading people, trust, and organizational performance are reliable. The results of reliability test of all research variables are presented in table 3 . The Cronbach's alpha is from 0.854 until 0.920 and the value is above 0.6; therefore, the reliability test in each of these research variables is trusted while the Composite Reliability each these research variables are greater than 0.7 , meaning reliable to be included in the hypothesis testing.

Table 3. Construct Reliability

\begin{tabular}{lccc}
\hline Variables & Cronbach's Alpha & Composite Reliability & Conclusion \\
\hline Leading Organization & 0.871 & 0.913 & Reliable \\
Leading People & 0.907 & 0.928 & Reliable \\
Trust & 0.854 & 0.901 & Reliable \\
Organizational Performance & 0.920 & 0.938 & Reliable
\end{tabular}

Source: Secondary data (2021)

Structural model results in table 4 shows that the R-square value for each dependent variable (endogenous latent variable). The R-square value for the Organizational Performance endogenous variable is 0.527, meaning the percentage of Leading Organization and Leading People that can be explained by Organizational Performance is $52.7 \%$ and the remaining $47.3 \%$ is explained by other variables not studied in this study. The R-square value indicates that the model belongs to a moderate classification. While R-square for Trust variable is 0.761 meaning the percentage of Leading Organization and Leading People can be explained by trust variable is $76.1 \%$ and the remaining $23.9 \%$ is explained by other variables that were not studied in this study. This R-square value indicates that the model belongs to a moderate classification.

Table 4. Determinant Coefficient Results

\begin{tabular}{lcc} 
Variables & R Value & Conclusion \\
\hline Organizational Performance & 0.527 & Moderate \\
Trust & 0.761 & Moderate \\
\hline
\end{tabular}

Source: Secondary data (2021)

The t-statistic test is intended to test the influence between variables. The result of the path coefficient is summarized in Table 5. The t-statistics is a statement of the value of significance of the relationship between one variable and another variable (significance level taken at error level of $5 \%$ ) and t-statistic value is 1.96. Each variable must have value more than 1,96 to have significant relationship between variables. 
Table 5. Path Coefficient

\begin{tabular}{lccc}
\hline Variables & Original Sample (O) & T-Statistics & P Values \\
\hline LO $\rightarrow$ TR & 0.095 & 1,175 & 0.241 \\
LP $\rightarrow$ TR & 0.795 & 10,101 & 0.000 \\
TR $\rightarrow$ OP & 0.726 & 11,707 & 0.000 \\
\hline
\end{tabular}

Source: Secondary data (2021)

In the relationship between LO and TR obtained that t-statistic value $1,175<1,96$ with $P$ values of 0.241 . This means that the relationship between LO and TR has a positive effect although it is not significant, thus $\mathrm{H} 1$ is rejected. In the relationship between LP and TR obtained that t-statistic value 10,101 >1,96 with P-values 0.000 . This means that LP has a positive and significant impact on TR, thus $\mathrm{H} 2$ is accepted. The relationship between TR and OP obtained that t-statistic value 11,707 > 1,96, and p-values of 0.000 . This means TR has a positive and significant influence on $\mathrm{OP}$, thus $\mathrm{H} 3$ is accepted.

\section{Discussion}

\section{Leading Organization and Trust}

The Leading Organization (LO) variable has positive but not significant effect to Trust (TR) variable. In the tstatistic value $1,175<1.96$ with $P$ values of 0.241 . This means that the relationship between variables $L O$ and $T R$ has a positive effect although it is not significant, this is result contradicted with previous research by Koohang, 2015. The service industry is intangible and managed by each individual employee act as the agent who deliver the service and will need leader with good interpersonal skill (Anggiani, 2020).

\section{Leading People and Trust}

The Leading People (LP) variable has a positive and significant effect to Trust (TR). In the t-statistic value 10,101 $>1.96$ with P-values 0.000 . This means that LP has a positive and significant impact on TR. This is in accordance with the research from the scholars such as Waldman et al. 2001; Peterson et al. 2009 agreed that leadership is leadership element is important in determining the success in the organization. The leader in organization must have competencies and able to lead change and advance innovation. The leading in people must have mentoring, coaching and demonstrate good interpersonal communication skill and competencies as transformational leaders. These findings is similar result of previous studies that effective leadership is a required capability for elevating the trust within employees in the organizations (Gardner, Fischer, and Hunt 2009; Paliszkiewicz, Gołuchowski, and Koohang 2015).

\section{Trust and Organizational Performance}

The Trust (TR) variable has a positive and significant effect to Organizational Performance (OP) variable. In the tstatistic value $11,707>1.96$, and $p$-values of 0.000 . This means TR has a positive and significant influence on OP. This is in accordance in line with the previous research by (Davis et al. 2000; Mayer and Gavin 2005). The effective in leadership able to build the trust and will enhance the organizational performance.

\section{Conclusion}

Nowadays organizations must keep alert and adaptive to unforeseen events and the emergence change, such as the Covid-19 crisis, which created and increased uncertainty among the business and immediate impact to threats the organizations' performance. With the current Covid-19 pandemic, organizations suddenly must navigate and find mitigate solution to facing the challenges that arising across many areas in their organizations' internal operational.

As the findings of this study are the leadership, including leading the organization and leading people are the standards for the value of trust in the process of good management science and in improving the organizational performance. The findings of this study point to the relative importance of leading organization, leading people to elevate the trust and enhance the organizational performance in service sectors. The respondents of this research are Jakarta's residents and working in service sectors. Based on the results, leading organization is not significant impact to trust but has positive influence. While the leading people has positive and significant impact to trust and the trust has positive and significant impact to organizational performance.

The recommendation for managerial implication is develop blends training and leadership development into priorities in developing organizational strategy (Koohang, 2017). Furthermore, the research found implicitly, 
that leading leader people positively built with an order of trust values, can create innovation as the basis for developing organizational performance. Fixed orientation on compliance with a clear organizational vision and mission and executed in a business strategy, to get the expected results even though the pandemic is still ongoing.

The researcher suggests a further study to conduct similar research with respondents from other provinces in Indonesia and other industries to get a complete picture of leadership impact to trust and organizational performance in Indonesia. During pandemic Covid-19, the work from home order must be implemented. The employees who gained trust from the organization will perform beyond the expectation and will enhance the organization performance.

Managerial implication for effective leadership in service sector such as leading organization in dynamic environment, able to do change management, leading innovation, motivating employees, well-balance in values or principles, leading and resolving conflict, listening, empowering, interpersonal communication, influencing and being agile, being self-awareness, search feedback, time management, learning, understanding each individual characteristic or heterogeneity, and developing or sustaining the relationship among employees. In the global organization need for continuous learning and skills training by the leader and decision making is expected to be more decentralized, transformational leadership being more effective for service sectors in the on-going pandemic Covid-19.

\section{References}

Al-Madi, F. N.; Assal, H.; Shrafat, F.; \& Zeglat, D. 2017. "The Impact of Employee Motivation on Organizational Commitment." European Journal of Business and Management 9 (15) (July): 134-45.

Anggiani, Sarfilianty. 2020. "Effect of Transformational Leadership on Employee Creativity: Perceived Organizational Support Mediator (Study Empiric At Five-Star Hotels in Jakarta)." PEOPLE: International Journal of Social Sciences 4 (3): 1862-75. https://doi.org/10.20319/pijss.2019.43.18621875.

Avolio, Bruce J., William L. Gardner, Fred O. Walumbwa, Fred Luthans, and Douglas R. May. 2004. "Unlocking the Mask: A Look at the Process by Which Authentic Leaders Impact Follower Attitudes and Behaviors." Leadership Quarterly 15 (6): 801-23. https://doi.org/10.1016/j.leaqua.2004.09.003.

Collins-Kreiner, Noga, and Yael Ram. 2020. "National Tourism Strategies during the Covid-19 Pandemic." Annals of Tourism Research, no. xxxx: 103076. https://doi.org/10.1016/j.annals.2020.103076.

Dasborough, Marie T. 2006. "Cognitive Asymmetry in Employee Emotional Reactions to Leadership Behaviors." Leadership Quarterly 17 (2): 163-78. https://doi.org/10.1016/j.leaqua.2005.12.004.

Davis, James H., F. David Schoorman, Roger C. Mayer, and Hwee Hoon Tan. 2000. "The Trusted General Manager and Business Unit Performance: Empirical Evidence of a Competitive Advantage." Strategic Management Journal 21 (5): 563-76. https://doi.org/10.1002/(SICI)1097-0266(200005)21:5<563::AIDSMJ99>3.0.CO;2-0.

Gardner, William L., Dawn Fischer, and James G.(Jerry) Hunt. 2009. "Emotional Labor and Leadership: A Threat to Authenticity?" Leadership Quarterly 20 (3): 466-82. https://doi.org/10.1016/j.leaqua.2009.03.011.

Gill, Amarjit S., Alan B. Flaschner, and Mickey Shachar. 2006. "Mitigating Stress and Burnout by Implementing Transformational-Leadership." International Journal of Contemporary Hospitality Management 18 (6): 469-81. https://doi.org/10.1108/09596110610681511.

Koohang, Alex, Joanna Paliszkiewicz, and Jerzy Goluchowski. 2017. "The Impact of Leadership on Trust, Knowledge Management, and Organizational Performance: A Research Model." Industrial Management and Data Systems 117 (3): 521-37. https://doi.org/10.1108/IMDS-02-2016-0072.

Lee, Peter K.C., T. C.Edwin Cheng, Andy C.L. Yeung, and Kee hung Lai. 2011. "An Empirical Study of Transformational Leadership, Team Performance and Service Quality in Retail Banks." Omega 39 (6): 690-701. https://doi.org/10.1016/j.omega.2011.02.001.

Mastrangelo, Angelo, Erik R. Eddy, and Steven J. Lorenzet. 2014. "The Relationship between Enduring 
Leadership and Organizational Performance." Leadership and Organization Development Journal 35 (7): 590-604. https://doi.org/10.1108/LODJ-08-2012-0097.

Mayer, Roger C., and Mark B. Gavin. 2005. "Trust in Management and Performance: Who Minds the Shop While the Employees Watch the Boss?" Academy of Management Journal 48 (5): 874-88. https://doi.org/10.5465/AMJ.2005.18803928.

Paliszkiewicz, Joanna, Jerzy Gołuchowski, and Alex Koohang. 2015. "Leadership, Trust, and Knowledge Management in Relation to Organizational Performance: Developing an Instrument." The Online Journal of Applied Knowledge Management 3 (2): 19-35.

Peterson, Suzanne J., Fred O. Walumbwa, Kristin Byron, and Jason Myrowitz. 2009. "CEO Positive Psychological Traits, Transformational Leadership, and Firm Performance in High-Technology Start-up and Established Firms." Journal of Management 35 (2): 348-68. https://doi.org/10.1177/0149206307312512.

Schaubroeck, John, Simon S.K. Lam, and Ann Chunyan Peng. 2011. "Cognition-Based and Affect-Based Trust as Mediators of Leader Behavior Influences on Team Performance." Journal of Applied Psychology 96 (4): 863-71. https://doi.org/10.1037/a0022625.

Škare, Marinko, Domingo Riberio Soriano, and Małgorzata Porada-Rochoń. 2021. "Impact of COVID-19 on the Travel and Tourism Industry." Technological Forecasting and Social Change 163 (April). https://doi.org/10.1016/j.techfore.2020.120469.

Verburg, Robert M., Ann Marie Nienaber, Rosalind H. Searle, Antoinette Weibel, Deanne N. Den Hartog, and Deborah E. Rupp. 2018. "The Role of Organizational Control Systems in Employees' Organizational Trust and Performance Outcomes." Group and Organization Management 43 (2): 179-206. https://doi.org/10.1177/1059601117725191.

Waldman, David A., Gabriel G. Ramírez, Robert J. House, and Phanish Puranam. 2001. "Does Leadership Matter? CEO Leadership Attributes and Profitability under Conditions of Perceived Environmental Uncertainty." Academy of Management Journal 44 (1): 134-43. https://doi.org/10.2307/3069341.

Wang, H. U. I., Sui, Y., Luthans, F., Wang, D., and Y. Wu. 2014. "Impact of Authentic Leadership on Performance: Role of Followers' Positive Psychological Capital and Relational Processes." Journal of Organizational Behavior, J. Organiz. Behav. 35, 5-21 (2014) 35 (November): 5-21. https://doi.org/10.1002/job.1850. 